\title{
LIMINALITY AND COMMUNITAS RECONSIDERED: THE POLITICS OF CASTE AND RITUAL IN GOALPARA, WEST BENGAL*
}

\author{
Frank J. KOROM \\ Department of Religion, Boston University \\ 745 Commonwealth Avenue, Boston, MA 02215 USA
}

\begin{abstract}
This paper concerns a local Bengali deity named Dharmaraj, whose worship in eastern India was quite extensive in medieval times. Today, however, ritual performances in his honor are confined to three contiguous districts of West Bengal. This decline in worship is partly due to the co-optation of a predominantly lower-caste deity by Brahmins. The degree to which "Sanskritization" has altered the practices associated with the deity shall be explored in both historical and ethnographic contexts based on medieval Bengali literature and anthropological fieldwork. The aim is to understand how the deity can be manipulated ideologically over time to serve the interests of different caste groups. I wish to sketch the dynamics of how Dharmaraj is currently constructed, interpreted, and understood in one small village - Goalpara - located in Birbhum District, the center of the deity's worship.

To do this, I will present data pertaining to annual puja, or ritual performance, for the deity. Ritual data will be supplemented with exegesis provided to me by a cross section of individuals belonging to various castes within the village. I intend to conclude by suggesting that the deity serves a mediational role in the village by resolving conflicts resulting from caste hierarchy. Moreover, his annual puja, although not levelling social status, displays a strong sense of Turnerian communitas, which allows for a temporary form of egalitarianism in which members of all castes gain access to the deity.
\end{abstract}

Keywords: Eastern India, Bengal, deity Dharmaraj, ritual performance, community

\section{THE PLACE AND ITS PEOPLE}

Goalpara is an all-Hindu community located in the district of Birbhum. It is divided into two directional sectors called Purbapara (eastern neighborhood) and Pashcimpara (western neighborhood). The boundary line between them is a youth club built in a small clearing marked by a tube well. These two major divisions are recognized by residents who often refer to them as major points of orientation within the village. By comparison to other villages in Birbhum, Goalpara is quite small; it is populated by 915 residents living in 166 households. Although the village is numerically and economically dominated by Brahmans, a total of fifteen castes are represented. Brahmans also dominate the village economy due to their landholdings, and

* A longer version of this paper will be published in Acta Ethnographica Hungarica under the title of "Caste Politics, Ritual Performance, and Local Religion in a Bengali Village: A Reassessment of Liminality and Communitas." 
many of the lower caste members of the village are employed by them as agricultural laborers. While a number of non-Brahmans own land, their plots tend to be much smaller, functioning mostly as domestic gardens. Brahman tracts are considerably larger and require more labor-intensive care in order to yield cash crops such as rice. ${ }^{1}$ A reciprocal interdependence is thus created: Brahmans must rely on the services of the lower castes, while lower castes rely on Brahmans for a portion of their income.

Brahmanical dominance is not just limited to the agricultural and economic spheres. Brahmans also control, or are at least tangentially involved in, most of the local ritual activities. The type of Brahmanization that has been occurring in Goalpara is not one-sided, however, for a number of influences also pass in the other direction. This seems to be the case in the Dharmaraj pujja, the topic of this paper, which was a completely low-caste phenomenon for a lengthy period in the past. Now, due to increasing Brahmanical participation, the pujjā is slowly taking on a number of Sanskritic features without necessarily sacrificing many of the local practices associated with Dharmaraj (e.g., pig sacrifice and liquor consumption). ${ }^{2}$ In other nearby villages that celebrate the Dharmaraj pujjā, the degree of Sanskritization has been greater, totally substituting blood sacrifice with the cutting of gourds and the ritual use of alcohol with milk. ${ }^{3}$ The replacement of vegetarian sacrifices for blood offerings does not seem to be an issue in Goalpara. Since Brahmans, who eat portions of the sacrificial flesh, feel that they must officiate at the balidann (goat sacrifice) on the third and final evening of the pujja a, there is no division of opinion on this issue. My own observations coupled with folk exegesis suggest that two sets of rites - one distinctively low caste, the other Brahmanical - exist side by side. ${ }^{4}$

There is a strong sense of caste interdependence in the domain of ritual, but it is also the ritual realm within which social hierarchy is contested. The Dharmaraj pujja is, perhaps, the most compelling example of this in rural Bengal. The püjä, sometimes called gajjan (thundering) in the region, is an occasion allowing for a great deal of participatory interaction by residents from all economic and occupational streams

\footnotetext{
${ }^{1}$ It is worth noting here that Dharmaraj also owns 12 bighās (= app. 4 acres) of land controlled by the dharma sarkār (Dharma committee). The profit generated by farming this land is used for partially funding the annual Dharmaraj püjā. According to oral history, a wealthy jamidār (landholder) from an adjacent village called Taltor donated the land for this purpose.

2 Almost two decades ago, it was reported that a Dom woman once remarked in conversation during the pujjā that Dharmaraj was their caste deity. Once the Brahmans began noticing the increasing popularity of Dharmaraj, however, they consciously decided to become involved in the püja by asserting their influence in the ritual domain. This is attested by the following statement: "Dharmapuja belongs to the Dom. It is our puja. Because the deity is so great, the Brahmans wanted to worship him" (ROHNER and CHAKI-SIRKAR 1988: 110).

${ }^{3}$ The term "Sanskritization" was first coined by the Indian anthropologist M. N. Srinivas in his landmark monograph Religion and Society among the Coorgs of South India (1952). I use the term here in the sense defined by STAAL to signify "a process by which a lower caste attempts to raise its status and to rise to a higher position in the caste hierarchy. Sanskritization may take place through the adoption of vegetarianism, of teetotalism, of the worship of 'Sanskritic deities,' or by engaging the service of Brahmans for ritual purposes" (1963: 261).

${ }^{4}$ For a more extensive discussion of this issue, see KOROM 1999.
} 
of life. In Goalpara, even the outcast leatherworking group known as Ruidas ${ }^{5}$ must participate in the pujja, for their drumming is essential to the overall success of the rites for Dharmaraj. As I begin to describe the social structure of ritual specialists, this point will be explored in more depth. For the time being let me just point out that activities on the all-village level, such as the Dharmaraj $p u \bar{j} \bar{a}$, display a much stronger sense of Turnerian communitas (TURNER 1977: 131-165) than exclusively small-scale caste events. The performance of songs for the rain goddess Bhajo (bhäjo $g \bar{a} n$ ) on the last day of the month of Bhadra by members of the Ruidas caste, for example, is limited to their own demarcated environment. The performances often do not flow beyond the inner, domestic compounds of their homes. Large-scale public display events, however, such as Dharmaraj püjā, happen primarily near the sacred spaces dedicated to this deity within the village, drawing people from all castes into worship.

\section{EMIC GENRES OF DISPLAY}

Püjās in Bengali culture are always sacred events. They are punctuated times for worshipping specific deities; times for Hindus to reaffirm their relationship with the gods and goddesses who play central roles in their lives, thereby insuring the wellbeing (kalyạn) of the community in question. ${ }^{6}$ The term püjā may be derived from the Sanskrit verbal root $-\sqrt{p \bar{u} j^{\prime}}$ which literally means "to make pure," "to cleanse," or "to purify" (APTE 1985: 628)..$^{7}$ The tentative etymology of the word is certainly one aspect of its use in everyday discourse, since there is a cleansing process through worship that renews the community. Concerning püjā in Bengal, Ákos ÖsTÖR has

${ }^{5}$ Ruidas is the Bengali variant of Ravidas, the untouchable Chamar (camār) holy man of Banaras. This is the name by which they refer to themselves as a distinct community. According to the caste's sacred oral tradition, they were told to stop eating beef by an emissary of the guru and adopt his name as their caste title in an attempt at upward mobility. However, other people in the village refer to them by their caste title of Bayen ( bājen), which was probably attributed to them due to one of their caste occupations as drummers and musicians (cf. SEN 1971.2: 621). Ruidas are also called mucí (cobbler), another common term for Chamars. On the background of the caste and their customs, see RISLEY 1981.1: 175182. On Ravidas' life and teachings, see SINGH 1981.

${ }^{6}$ There has been some controversy over the meaning of the term kalyān. In her study of prestation in a Hindi-speaking village in Uttar Pradesh, RAHEJA (1988) translates the term as "auspiciousness." ROBINSON (1980: 172) makes a similar assertion regarding the use of the terms kalyanni and manigal in Bengali. I find this problematic, however, since she also uses a number of other terms such as subh to mean the same thing. For a comment on the semantic problem in Hindi, see Korom 1990: 549. While it is true that a major Bengali thesaurus (MUKHOPĀDHYĀY 1990: 237) lists kalyān as a synonym for śubh, I feel more comfortable translating the former as "well-being," since this rendering is more common in everyday discourse.

7 The etymology and subsequent meanings of the term püjā have a long history of debate in Indological studies concerning whether or not the term is a Dravidian loanword in Sanskrit (cf. BAILEY 1961; THIEME 1957). Some have even suggested a double origin of the term in both languages. But more recently, RADHAKRISHNAN (1965) has shown linguistically that the word must have been borrowed into Tamil. Whatever the true origin of the word, the meaning still seems clear, and I follow APTE here for conceptual, rather than linguistic, reasons. 
stated that "As an idea puja expresses a relationship between the human and the divine, earth and heaven. As an act it signifies the way men approach deities: a symbol of offering as much as an expression of the act of offering itself. A system of classification, a logic of categories and a whole philosophy is expressed through the meanings of puja symbols" (1982: 21). A philosophy yes, but not one based on printed literature. Rather, residents tend to de-emphasize the centrality of textual narratives in their tradition, favoring instead orally transmitted stories about Dharmaraj's first appearance in the village.

Residents speak of the Dharmaraj püjā in functional terms reminiscent of older anthropological paradigms of myth and ritual proposed by MALINOWSKI (1954). When asked why the rite is performed most residents would respond in two ways. First, people generally say that "we perform the pujjā so that we may get happiness" (jâte $\bar{a} m r \bar{a}$ annanda $p \bar{a} \bar{t}$ ). When pressed on the issue they generally provide a cause and effect answer: "We perform $x$ in order to get $y$." The pujjā therefore has a very pragmatic dimension. Not much time is spent speculating on the nature of Dharmaraj and his worship, yet virtually everyone in Goalpara seems to know something about him, for normative claims concerning him are often expressed in very subtle and sophisticated ways (KOROM 1997b). In many parts of Bengal, the term gajjan (thundering) is used to refer to the event. This word is only used in a very specific sense in Goalpara today to refer to one performance that occurs during the rites. ${ }^{8}$ Instead of gājan, the term melā is sometimes used interchangeably with püjā when talking about the dharmānușthān (Dharma function or event). But most often melā is employed alongside the term püjā to discuss the so-called profane (apabitra) dimensions of the overall event.

Melā means "gathering," "meeting," or "assembly" (SEN 1971.2: 778). These connotations are embedded in one of the current uses of the word to mean festival. ${ }^{9}$ The Dharmaraj pujja is, in other words, a time for celebration and relaxation as well as spiritual dedication and reflection. It could also be said that pūjā demonstrates the willpower of ascetic lack and sacrifice, while melā allows for licentious behavior, conspicuous display, and consumption of goods. It is a time, as Roger ABRAHAMS states about the language of festivals, "for bringing out, passing around, for giving and receiving the most vital emblems of culture in an unashamed display of produce" (1982: 161). ${ }^{10}$ In this sense, the Dharmaraj pujjā transcends sacred and profane,

${ }^{8}$ SEN 1971.1: 218 translates the term literally as "shouting." He himself, however, traces the word to garjana (thunder), the form in which it is used in Goalpara to distinguish it from Shiva's gajjan. It can also be translated as "roar." In the village, the term is used for the rite known as megh garjan (cloud thunder).

${ }_{9}^{9}$ Etymologically melā does not imply the same thing as the Latin festum (merriment, revelry), from which the word festival derives. But melās are indeed considered to be occasions for public displays of joy. The qualities and characteristics of melās fit in well with FALASSI's structural typology of festivals as rites of passage, reversal, conspicuous display, and consumption. See FALASSI 1987: 4-5.

${ }_{10}$ While ABRAHAMS is thinking of festival behavior in a more universalized sense, his ideas tie in nicely with Hindu notions of exchange and transaction as analyzed in MARRIOTT 1976: 109-142. Also, as BOURDIEU $(1977,1989)$ has suggested, the "size" of the public event and calculating the number of people in attendance should be factors considered when discussing exchange as a display of wealth, but we need not follow his rationale of this to the letter as a "display of symbolic capital." 
allowing residents an occasion for religious fulfillment in a congenial and celebratory environment that takes the performance of religious rites out of the temple precincts and into the marketplace. While this dimension of the phenomenon is no less significant (cf. KOROM 1999), I wish to focus on the political and spiritual dimension of the pujjā here, for it provides us useful insights into how caste tensions can be defused periodically within a socially sanctioned environment of display.

\section{THE WORSHIP OF DHARMARAJ CONSIDERED SPATIO-TEMPORALLY}

In medieval times Dharmaraj pujjā was celebrated primarily in the "core area" known as Rarh (rärha), which served as the historical stage for the events narrated in the Dharmamangal literature upon which the deity's worship was founded. Dharma worship flourished along with this epic literature and may have spread into the contiguous areas of Bihar in the west, Assam in the northeast (NEOGI 1951), and as far south as northern Orissa. But due to historical exigencies, the decline in the recitation of the literature, and gradual absorption into other modes of worship (especially Shaivite), Dharmaraj's communities of devotees shrank considerably in size, only maintaining a strong foothold in the Rarh region. Ethnographic evidence from the 1950s, however, suggests that the ritual performance was more widespread (BHATTACHARYYA 1952, 1953) even in the modern period. The most popular gājans or pujjās are performed presently in Bankura, Burdwan, and Birbhum, with the highest concentration found in the last. They are mostly celebrated during the hot and rainy seasons - from Baishakh ( baiśákh = April-May) to Shraban (śrāban = JulyAugust) - to ensure the advent of the rains and the subsequent rice harvest, although a few minor pujjās in honor of Dharmaraj are held during the winter months.

The Dharmaraj püjā carries varying degrees of importance from place to place. In towns such as Beliatore (Bankura District) the ritual is a huge and elaborate affair known throughout Bengal. But in most of the villages celebrating Dharmaraj's presence, the ceremony is small-scale, attracting only people from the immediate environs. It is perhaps unusual that Dharmaraj is the paramount deity in Goalpara, but because he is given the title of grāmya debatā (village deity) he is believed to be the guardian of the village, the protector of devotees, and the persecutor of wrongdoers. Everyone in Goalpara unquestioningly states that Dharmaraj is the most important deity in the village, and that his pujja is the largest and most important in the annual festival cycle. ${ }^{11}$ There is also no question concerning the efficacy of worshipping Dharmaraj: he must be appeased for the individual and collective well-being of the

\footnotetext{
11 One of the criteria used by people in Goalpara to judge the importance and success of an event is its "bigness." The term ba pra (big) and phrase khub bara (very big) are used to signify the size and stature of an event or person. Thus the phrase bara lok (big person) is used in Bengali to signify a rich or influential man. This idea may be part of a larger "folk aesthetic" in Indo-European notions of performance. On "bigness" as a concept in Europe and America, see GOLDSTEIN 1991.
} 
community, as the personal experience narratives I have discussed elsewhere attest (KoROM 1997c).

Although a certain Brahman living in Goalpara performs a daily püjā at the village temple housing the Dharma sila (stone), the focus of community worship is on the annual celebration. The annual performance of Dharmaraj's worship is considered even greater than the pujja for Durga, which is without doubt the largest and most popular religious celebration in West Bengal. Dharmaraj's centrality is also suggested by statements we find in the origin narratives told in the village to account for the unique timing of the pujja during the month of Chaitra (caitra = MarchApril). I have discussed these narratives at great length elsewhere (e.g., KOROM 1996, 1997c), so I do not wish to dwell on them here. It is necessary, however, to point out two important orienting factors. First, according to the master narrative of the village's oral tradition, Dharmaraj himself appeared in Goalpara and stated that he should be worshipped in the village. In community elder and master storyteller S. P. Chattopadhyay's version of the story, Dharmaraj appears in the guise of a Brahman to a herder boy (bāgāil) and proclaims that the püjā should occur on the pürṇimā (full moon) of the month of Chaitra:

nā āmi ekhāne ābirbhāb haba. tumi jene rākha je ei grāme ei jāỳgāy āmi thākba.

Well, I will appear here. Keep in mind that I will stay in this spot, in this village.

āmār pūjā karbe àr grāmer bhìtare āmār ek angśa prastar khậ̣̂a niỷe giye

Worship me and take a piece of rock which is a part of me inside the village

grāmer bhì tare sthāpanā karbe. sekhāne püjā habe.

[and] establish it inside the village. There will be pujjā there.

pūjātà habe caitra pūrṇimāỳ. caitra pūrnịimāy ei pūjā habe.

The pūjā will be on Chaitra pürṇimā. On Chaitra pūrṇimā this very püjā will happen.

Chaitra is the last month of the Bengali year, and the worship service is held, as the narrative states, on pürnimā, the full moon. In reality, this makes Dharmaraj pujja the last ritual of the year, falling just before the beginning of a new cycle. Residents of Goalpara see it as the first pujja of the new year because it falls at a time of transition, foreshadowing all other village observances to follow during the next cycle. In this sense, the ritual itself is situated in a liminal zone. The Dharmaraj pujja thus suggests both opening and closure. It is simultaneously a time to end the festival cycle and a place to begin. It provides, in Jonathan Z. SMITH's terms, "a place upon which to stand," a punctuated period providing the village's basic religious orientation. As SMITH writes, "There is... the possibility of a real beginning, even of achieving the Beginning, a standpoint from which all things flow, a standpoint from which...[one] may gain clear vision" (1978: 289). Such a period of collective action is also an appropriate time to reflect on social distinctions and caste hierarchy because 
everyone in the community is obliged to participate economically and ritually in the event.

A version of the aetiological narrative told to me by S. P. MUKHOPADHYAY, the püjāri (ritual specialist) who performs daily services at Dharmaraj's temple, confirms that the deity appeared in Goalpara prior to manifesting himself in other locales in the district. For this reason, the people of Goalpara view their pūjā as the most important one in the area, the origin of origins. As MUKHOPADHYAY states:

āmi motāmoti jețā pūrbapuruser kāch theke sunechi sețā hacche ei dharmarāj thākur That which I have roughly heard from the ancestors is that this very Dharmaraj lord

rājāa ballāl sener āmal theke haỳe āsche. ār ki?

has come down from the time of King Ballal Sen. ${ }^{12}$ And what else?

kathita āche je ei dharmarāj thākur, māne bises kare bīrbhūm dịstriker pratham sthān. It is said that this very Dharmaraj lord, I mean especially Birbhum District's first place.

māne āmāder ei goyālpārāă theke ābirbhāb haỷeche.

I mean from our very Goalpara [he] appeared.

The passage suggests a unique position for Dharmaraj in Goalpara, and succinctly voices indigenous concepts about Dharmaraj's primary role in village worship. In other words, it is said that Dharmaraj should be worshipped first and foremost in Goalpara. From the point of view of the residents, Goalpara is the center of Dharmaraj worship, and his pūjā is central to the village's ritual activity. A line from a printed version of Dharmaraj's origin narrative (MITRA 1972: 127) clarifies the point to an even greater extent:

e añcale jata dharmapūjā haý, sabār āge āmār pūjā cāi

In this region, however many Dharma pujjās there may be, I want mine to be before them all.

12 Ballal Sen was the second in the line of the Sen kings, who ruled a great portion of Bengal for over 125 years. He was the son of Bijay Sen, who died in $1158 \mathrm{CE}$, leaving his kingdom in the hands of his son. See MAJUMDAR 1943: 216-218. This suggests a very long period of development for the püjā, but it is necessary to approach the historical reference with caution, since Ballal Sen, for reasons unknown to me, has become a sort of folkloric figure and culture hero in Bengali oral and popular tradition, and many features of Bengali culture are often traced back to his reign. It is highly questionable whether any of the Dharmamangal literature in its preserved form dates back to the 12th century (cf. SEN 1975: 141), but it is quite possible that the worship of the deity predates any of the texts or their rise in popularity. SEN (1975: 163), however, notes that an obscure early 18th-century text titled Niranjanmangal describes a chance encounter between the Dharmamangal's hero Lausen and Ballal Sen. This fact links the mythic, historic, and legendary. On mythological knowledge during Ballal Sen's period of rule, see HAZRA 1985. 
Such pivoting of the sacred grounds belief and practice in one distinct location. But unlike many larger and more popular sites of kratophany (manifestation of power), as ElIADE has termed them (1958), Goalpara's locus of power does not have a written tradition associated with it, as I have been stressing. Instead, the importance of the place, time, and performance of the Dharmaraj $p$ üj $\bar{a}$ is maintained and perpetuated by a corpus of oral narratives about his first appearance in the village..$^{13}$ Let us now move on to a consideration of ritual actions taken by the key actors involved in the pujja to provide more texture for situating my concluding discussion of liminality and communitas.

\section{DOWN BY THE RIVER}

Bathing and ritual purification play a major role in Hindu rituals, so they must be performed prior to worship. As Lawrence BABB has stated, "the principal actor or actors in ritual must themselves be in a purified condition before approaching the deity" (1975: 47). Purity before the deity is a necessary precondition of worship in virtually all Hindu rituals, and purification must be performed if a rite is to be effective. Running waters are the most powerful means of purification because the river "both absorbs pollution and carries it away" (ECK 1981: 217). To accomplish this task in preparation for the pujja, Subodh Chattopadhyay, a Brahman youth from the village, makes arrangements for a bus to transport village residents to a place on the banks of the Ganges known as Uddharanpur two days before the püjā begins. Uddharanpur is located approximately one hour south of Goalpara by road. The scenic spot is a popular local pilgrimage site because the Ganges broadens there into a gently flowing river. ${ }^{14}$

When the bus arrives in Goalpara at 5 a.m. on the 24th of Chaitra (April 7, 1990), pilgrims of all castes, are waiting to board. The seating arrangement did not necessarily break down into caste groups, but it was clear that clusters of caste-based friends had formed on the bus both to and from the river. The atmosphere was not, strictly speaking, one of sacredness; rather, the trip served the additional purpose of allowing people to take a leisurely break from their daily routines. This was especially true for many of the women on board, who told me that they saw the occasion as an opportunity to gossip with their friends and to get away from their husbands,

\footnotetext{
13 These themes are the subject of other studies authored by me. See KOROM 1996, 1997a,b,c, 1999.

14 The Ganges (gangā) rose in prominence some time after the decline of the Indus Valley civilization, and eventually became the archetypal sacred waters. Her name means "going" or "motion," coming from the root gam (APTE 1985: 399). Her waters are swift and powerful, for she is sakti, female energy in the form of water. Because the Ganges is considered to be a symbol of life and fertility, she incorporates all potentialities in her water. She is the fons et origo, the source of all possible existence, for water is without form. From this formlessness springs forth all potentiality. In her all seeds are contained. She is literally the germ of life. Symbolically, she is that void from which all things come, and to which they must return in the end. She gives life in the beginning and accepts death in the end. For more on this line of reasoning, see ELIADE 1958: 188ff. On the mythology of the Ganges, see ECK 1986: 166-183.
} 
while simultaneously accruing punya (merit) by bathing in the Ganges, the mother of all rivers.

As soon as we arrived, everyone proceeded to the river. The pilgrims then proceeded to the bathing ghăt (steps) and purchased white sugar candy ( $\mathrm{mol}$ ) to offer the river during the bathing rite. As people began purchasing their offerings, they gradually segmented into family and caste units, wandering to different spots along the river to bathe. One by one, the pilgrims began to move down the steps toward the water. Brahmans performed the gāyatri mantra in praise of the sun, while other castes simply hailed Ganga, the river goddess. After each person finished their bath, they filled pots with water and clay, then washed their clothes in an informal ritual to purify clothing as well as body. ${ }^{15}$ While clothes were drying, the Goalpara group moved around the pilgrimage complex, purchasing souvenirs such as religious pictures, chapbooks glorifying the site, and shopped for fried snacks (bhäjā) and sweets to eat along with the muri (puffed rice) brought from home.

No one ate until after everyone had finished bathing. A scenic, quiet spot a short distance from the river was discovered by one of the children, and everyone sat in small groups eating large mounds of puffed rice mixed with water, raw chili peppers, fried snacks, and sweets. People were quick to point out that one should not overeat from this point onward because partial abstinence was one obligatory aspect of the observances that must be kept during the pujja, especially for those individuals who would become the devotees (bhaktyās) of Dharmaraj. Conversation during the meal was mostly about the forthcoming püjā. A main concern among the women was the amount of housework and cooking they would have to do for guests and relatives. Those to become bhaktyās were gathered in their own circle, discussing the activities that would take place during the pujja and why each had taken on the responsibility of becoming a temporary renunciant. The children played after their meal, while the remainder of the men talked about all of the fine liquor that would be consumed on the last day of the pujja. Conversation went on in this manner for approximately two hours, at which time Subodh assembled us for the return journey, and by 1 p.m. we were back in the village. The pilgrims returned to their homes to share prasād with family members. Local pilgrimages of this sort are standard practice in north India (cf. GOLD 1988), for whenever a great religious event approaches, it is desirable to bathe in the Ganges, especially for those people who have made a mānasik (vow) for the occasion.

What is it, then, that makes water such a powerful symbol? How is it that seemingly dirty water can bring about an ontological change in the pilgrim? Pilgrims simply told me that the bath is performed to clean body and mind prior to the pujja. In order to enter the realm of the sacred one must be pure. Ritual purification offers the pilgrim the opportunity to place himself back into the sacred sphere from whence we came by removing the finite and impure activities of existence. Goalpara

\footnotetext{
${ }^{15}$ It is interesting to note that women do not escape housework by going on such journeys, but creatively incorporate activities such as washing into the leisure-time activity itself. This phenomenon is fairly widespread in North India. For another example, see KUMAR 1988:83-110, esp. 89.
} 
residents echoed this by acknowledging that the exigencies of daily life make one impure. Therefore, bathing must be a prerequisite to worship. Historians of religions have taken this idea one step further by interpreting the act as a primal event. As Frederick STRENG has noted: "To purify means to return to a powerless form, the original power, which in itself is pure" (1969:92).

The bathing process constitutes a "rite of separation" (VAN GENNEP 1960) from the previous life, a symbolic rebirth into a new and pure condition. It is a total regeneration during which physical form becomes as boundless as the water into which it is immersed. It is a total "reintegration into the formlessness of preexistence," as Mircea ELIADE has stated (1958: 188). By emerging from the water, the pilgrim "becomes a part of the act of creation in which form was first expressed" (ibid.). It is an act which is repeated over and over again during the course of the pujja. One contemplative Brahman pilgrim explained this symbolic interpretation of scholars as an act of parturition, describing the Ganges as $m \bar{a}$ (mother) and bathers as her children being born from her waters.

By partaking in the sacred repetition of bathing, the pilgrim experiences the whole of time. From the moment one emerges from the water until the moment one again performs the act of immersion, the cycle of time is theoretically experienced. This cycle can be interpreted on two levels: On the human level immersion is equivalent to death, and emergence can be seen as a new birth, for the pilgrim comes out of the waters as a child without any sin (pāp). On the cosmic level the immersion could be interpreted as symbolic of pralay (cf. ZIMMER 1974: 3-22), the cataclysmic flood which periodically dissolves existence as we know it into the allengulfing primeval ocean of milk, the kssirsāgar (milk ocean). The world is once again created anew after this cataclysm, continuing the endless cyclical pattern of time. Although a phenomenological interpretation such as the one presented above might lend meaning to our symbolic understanding of the event as an essential representation of the cyclical and transient nature of Hindu time reckoning, residents would not see it this way. For them, the separation is only temporary and has no conscious cosmogonic significance. However, one village resident did confirm that the bath washed away sin, while another curious bystander who overheard our conversation chimed in, saying that the bath allows one to go home anew (natun kare).

Those who are able to attend the annual outing think of themselves as having achieved something special. They say that they feel pabitra (sacred), and are ready to begin their participation as audience and performer in the annual rites. But while I have discussed briefly the process of bathing as an entry into the pure realm of sacred activity, I do not want to overemphasize the sacred dimension over the profane; nor do I wish to separate the two realms completely, for as we have seen, the journey also entails a dimension of leisure, a free-time activity. Pilgrims clearly see these two forms of activity as inseparable. This is true of the whole püja phenomenon as well, as I have attempted to suggest elsewhere (KOROM 1999).

I have hinted above that the bathing rites are structurally similar to rites of passage in the sense defined by Arnold VAN GENNEP (1960) and elaborated by Victor TURNER (1973, 1974, 1977, 1979). While the entire pujjā event could be inter- 
preted as a periodical rite of passage for the whole community, the bhaktyās, to whom I turn below, go through a more specific transformation of status because of their special role in the rituals.

\section{BECOMING A DEVOTEE}

The bhaktyass (or bhaktas $=$ devotees) are a special class of people who, for numerous reasons, such as vows (mānasik), money, comradery, happiness (ānanda), or the general well-being of family and community, volunteer to perform austerities during the three days of rituals. The greatest number of devotees by far come from the lower castes of the village. Although the total of twenty-seven bhaktyās are dominated by Lohars, they come from four castes in Goalpara, including two Brahmans, three Haris, and two Doms, the latter belonging to the untouchable class. The bhaktyās perform their austerities not for specific reasons, but for the well-being of their family. This reason is given by devotees who perform such austerities in other villages as well. My information closely corresponds to the statement made by R. M. SARKAR concerning devotees from other places in Birbhum. He writes that while many bhaktyās have specific vows in mind when they become devotees "all are centered round the general well-being of the person or of the families" (1985: 266).

As suggested elsewhere (KOROM 1997b), the pujja is becoming increasingly dominated by Lohars as Doms, who originally claimed proprietary rights over the $p \overline{u j} \bar{a}$, decrease in population in the village. It is very common to hear Lohars refusing to accept the claim of the Doms, stating that Dharmaraj has always been their caste deity. On one level, everyone says that Dharmaraj is the village deity (grāmya debatâ), but on a more subtle level Lohars tend to construct their own caste identity around him. Such caste competition, however, does not impinge attempts to abolish caste hierarchy among the devotees during the ritual period. As I demonstrate below, however, this is an imagined equality more akin to a Weberian ideal type. In reality, distinctions are made, not only during social interaction but also in the context of the rituals performed. Egalitarianism is an ideal, but cooperation is the reality for which pujjā participants strive. The bhaktyās' entry into special ritual status begins with the bathing journey, but this is a phenomenon in which anyone can take part, so another rite takes place after returning from the river to mark the beginning phase of their social transformation.

After returning to Goalpara, the bhaktyās go to the youth club in Pashcimpara, where they are met by the village barber (nāpit). He performs bhakta kāmanna (devotee shaving) by giving each of the devotees a haircut, trimming their mustaches, and shaving their armpits. The act of tonsure parallels the Brahmanical upanayana (sacred thread investiture) ceremony which marks a Brahman's entry into twice-born status (ROBINSON 1980: 188). Similarly, the kāmanna ceremony begins the process of ritual transformation experienced by the bhaktyās. This act is seen as paradigmatic of being a bhaktyā, since all of their subsequent performances during the püjā are described as kāmāna. Shaving body hairs is therefore understood to be 
an act of personal sacrifice, like all other forms of austerity (tapas) to be practiced during the event. For his labors, the barber receives the shank of a sacrificed goat on the last evening of the pujja. However, the barber did not shave everyone present. While he was shaving devotees of the Lohar caste, the Haris shaved each other. The two devotees of the untouchable Dom caste did not even show up, since they shaved themselves at home. This was true of the Brahman bhaktyās as well, who performed the rite in their own courtyards. Thus, both "highest" and "lowest" castes were forced by traditions of relative purity and pollution to do it for themselves. It is interesting to note that during my first conversation with veteran bhaktyā Mukti Hajra, he explained to me that everyone is equal (sabāi samān) during the pūjā.

Recorded statements like Mukti's pronouncement, have led some anthropologists to use TURNER's paradigm of communitas without verifying the accounts. Although subalterns (mostly low caste) like Mukti assert communitas even while continuing to observe difference, there is a distinct sense that the ideal can never be actualized, as I would like to suggest in my conclusion. The low-caste yearning for equality is quite different from Brahmanical interpretations, which tend to reinforce notions of hegemonic power over other members of the village. What results is an emic ambiguity concerning exactly what sort of transformation occurs during the performance of rituals. Brahmans and other high castes maintain that Lohars and Doms never achieve a status change, while low-caste devotees insist that they do indeed elevate their position, albeit temporarily. This sort of reasoning should suggest a need to use TURNER's musings with selective caution. While his notion does retain a measure of analytical value and might be useful in some contexts, it does not have the universal applicability he originally intended. However, the rites of passage model is a useful one for understanding the temporary transformation undergone by devotees prior to and during the rituals. I shall return to this notion in the concluding section, but for the moment, let us return to the devotees.

While the shaving ritual is in progress, the bhaktyās sit on the ground joking, smoking, and talking about all of the events to take place over the next few days. Much conversation focused on the large quantities of alcohol that would be consumed on the last day of the pujja. The consumption of alcohol is not seen as a profane act, since it is said that Dharmaraj himself is very fond of drinking. Antinomian religious behavior such as intoxication is justified by linking the act of consuming alcohol with an activity in which the deity also engages. By identifying the deity with such human vices, as one resident put it, humanizes Dharmaraj, making him more accessible and comprehensible to the average worshipper. Drinking thus becomes a sacred activity that combines service (seba) for the deity with the pleasure of intoxication (neśâ). As chief drummer Sushil Das remarked one evening when he was playing the special püjā rhythms on his $d_{h} h \bar{a} k$ for me:

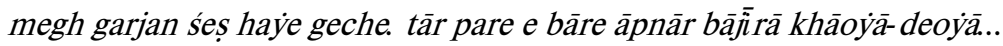
Megh garjan has finished. After that, this time, your musicians eat... 
khāoỳā-deoýā balte... mad [hāsya]! bābā mad khete khub bhālabāse.

to say eat...liquor [laughter]! $B \bar{a} b \bar{a}$ loves to drink liquor.

āmār svajāti anek okhāne jān. kintu... alpa alpa mad khāj̀.

Many of my caste brethren go there. But...they drink quite a bit of liquor.

tāte neśā kintu pachanda haỷe jāý.

So there is pleasure in that intoxication.

ebañg āmār svajāti khubi ānanda lābh kare matan ei mad-țad khāoyār par.

And it is like my caste brethren attain very much happiness after drinking this liquor.

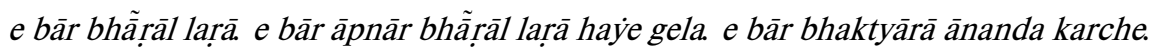

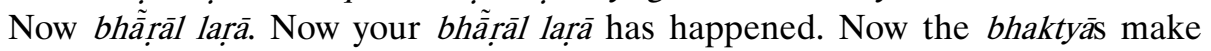
merry.

bāẩirāo ānanda karche. e bār oi āge du din je nāchanā bājanā bejeche,

The musicians also make merry. Now those last two days that dance music has been played,

sei bājanā bājiỳe bhaktyārāa ānanda karla bāî̀îāo ānanda karla.

after playing that very music the bhaktyās made merry, the musicians also made merry.

\section{e bār ānanda karte karte grām beriỷe hajejejāy.}

Now, while making merry they go around the village.

Drinking serves an important function during the pūjā as a mechanism for attaining happiness (ānanda). As Sushil suggests, villagers justify drinking by stating that $b \bar{a} b \bar{a}$ (i.e., Dharmaraj) himself loves alcohol. The logic here is that if it is good enough for the deity, it must be good enough for mortals. Drinking makes Dharmaraj happy, and if he is happy, so too is everyone else. The practice is not random, however, for bhaktyās must maintain a strict diet through partial fasting (upabās) once they have been shaved.

After the shaving is completed, the bhaktyās bathe once again in one of the many village ponds and return to their own homes to partake in their last full meal before the püjā. This last big meal, called bhārer bhät (filling rice), simple as it is, is a time for contemplating the seriousness of the forthcoming events, while simultaneously anticipating the joviality and transgressive behavior of the ritual's final day. The meal is another indicator of the bhaktyās' transition to a new status, for because they eat only boiled food without raw chilies, they see it as a common form of personal sacrifice. Later in the evening, after the meal, the bhaktyās gather together and "talk" (katha balā). The talk is informal and takes many forms. Ajit Lohar, the kol 
deyāâsi (head devotee) reviews the sequence of events for the next three days with his fellow bhaktyass. This is a sort of male bonding ritual that consolidates their special relationship as people set off from other participants. It also adds to an idealized sense of communitas imagined by the devotees during the event. ${ }^{16}$ On the next evening, the püja will begin at the Dharmaraj temple, when they receive their uttaríya, symbolic of the paitya (sacred thread) worn by Brahmans.

\section{INTENSE WORSHIP AND FESTIVITY}

The first day of the pujjā occurs two days before the full moon (25th of Chaitra, 1396 [April 8, 1990]). In the morning, everyone in Goalpara is busy making last minute preparations for the forthcoming events. The bhaktyās have already begun their partial fast and taken their first sacred bath of the day. As preparations are commencing in Goalpara, the dhākis in Shiyan are tuning their drums. Back home in Goalpara, people can be seen cleaning their houses, washing down the dirt paths in front of their homes for the purpose of purifying the route Dharmaraj will take when he is led in procession through and around the village. Children are playing throughout the area, especially near the Dharmaraj temple. In their play, they take on the roles performed by ritual specialists and musicians, and it is fairly common to see children pretending to beat imaginary $d h a \bar{k} s$ and $\underline{d h o k s, ~ o r ~ a c t i n g ~ o u t ~ t h e ~ v a r i o u s ~}$ rituals performed by the devotees. ${ }^{17}$ Essentially, this day is still one of normal activity, for everyone is completing their work schedules to allow for ample free time during the püjā.

By sunset all of the preparations are complete, and people begin congregating at the temple. With the exception of the Brahman bhaktyās, who already wear their own sacred threads (paitya), the remaining low-caste devotees sit to the sides of the temple winding together the seven strands of white cotton thread to serve as their uttarìyas after their consecration. The eventual donning of the uttari $\dot{y}$ a marks the second major event that signals the advent of changed status, but it also denotes an expression of subordination on the part of the devotee in the powerful presence of Dharmaraj. This practice is most likely related to the subjugation of a prisoner, as in the proverb (DE 1392 B.S.: 65):

galāý gāmchā dìye tẹne ānā

Placing a cloth around [one's] neck [in order to] drag

\footnotetext{
${ }^{16}$ The devotees' status is even more demarcated on the next evening when they say that they enter into dharma gotra (Dharma's lineage) as a result of receiving the uttariy ya, as discussed below. On changing from one's normal lineage to raise status during the püjā elsewhere in West Bengal, see also SARKAR 1986: 252; 297-298, footnote 7 .

${ }_{17}$ Acting as bhaktyās is a kind of informal training for future devotees, for I often overheard bhaktyās saying that they too learned about the ritual activities during their childhood play. Indeed, the rituals are indigenously labeled as khelä (play). See KorOM 1999.
} 
While they wind their threads, they wait for a new figure, the mül deyáâi to arrive from the nearby village of Taltor. ${ }^{18}$ When he arrives, he sits with the bhaktyās, locating himself closest to the door of the temple. By nine at night, Shibu $d \bar{a}$, the visiting Brahman ritual specialist who officiates the occasion, has arrived from his own village. The one large and two small bāneśvars, symbols of Dharmaraj's fecundity and power, have already been placed in full view on the veranda earlier in the day. Shibu $d \bar{a}$ is sitting cross-legged to the left of the objects as he signals his willingness to begin. The stage is now set for the transformation of the bhaktyās. The threads, now completely woven, are put into the custody of the priest by Ajit Lohar, the kol deyāāi mentioned earlier. A few more drummers are present, but the majority of dhākis from Shiyan will not arrive until the next morning.

The drummers pick up the pace of playing the pujjas s opening beat to let everyone in the vicinity know that the event is about to begin. This is the first of many special rhythms or laus (waves) played at different times during the next three days. Most people do not know the rhythms by their special names, since they are referred to loosely even by the drummers. But everyone knows the significance of each beat, and will recognize that the specific ritual performance associated with each rhythm is about to begin. As the opening rhythm sounds, Bipad Mandal, the organizing committee's secretary, ceremonially brings out a "folk-book" 19 wrapped in an auspicious red cloth and hands it to Shibu dā, who will read out the dharma bandanā (Dharma invocation) to the devotees. A heightened pace of drumming signals to everyone in the area that the pujja has started. When the audience is completely silent, Shibu $d \bar{a}$ begins reciting the text's couplets in a lilting, chant-like fashion. After the completion of each couplet, the bhaktyās, who are now standing and holding their threads (uttari $\bar{y}$ a dharan) with folded hands in front of the seated chanter, repeat the lines while gently swaying from side to side in a manner said to represent the movements of Dharmaraj's horse. ${ }^{20}$ When they have completed each repetition, the drummers begin to play very loudly as the bhaktyās lead the audience members in

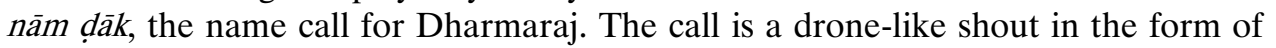

\footnotetext{
${ }^{18}$ The term mül means "root," and it is generally accepted that deyāâi comes from deb (deity) + angśa (portion). For a discussion of the latter's etymology, see BHATTACHARYYA 1975: 627-628. This title is given to the main bhaktyā who performs many of the key rituals on behalf of the entire group. In Goalpara, the position of mül deyāsì is hereditary, and was held in the early 1990s by Sudho Krishna Ghosh, an octogenarian member of the Sadgop (milkman) caste. Hierarchically, he is given more spiritual power than the kol deyāisi, who, is nonetheless functionally significant in his role as foreman of the devotees.

${ }^{19}$ On the characteristics, classification, and cultural importance of folk-books, see YASSIF 1987: 20-27. The book is actually an inexpensive primary school notebook containing some hand-written texts used at various times during the ritual. The text was written out in 1956 by the late Gaurishankar Mukhopadhyay, grandfather of Harishankar, currently the village's daily pujjāi $\bar{i}$. No one knows whether he wrote the text from memory or copied it from a book. The text does include some scribal errors, but it would be difficult to presume that this is due to a faulty memory or an inaccurate text. This is the only copy, and is securely kept in the secretary's chest along with the püjā ledgers.

${ }^{20}$ As village resident Shashthi Sutradhar stated to me, "Dharmaraj rides on a horse." This is a common belief in Birbhum District, where it is understood that Dharmaraj will often mount a white horse in the dead of night and ride through wooded areas and fields. See KOROM 1997b: 166-167.
} 
an exclamatory interjection similar to the English "oh." It rises in volume until the local name of Dharmaraj (Baharadihi) is vocalized, during which it slowly decreases until completed with the final expletive go (e.g. oooooh bābā baharădihi dharmarāj gooooo). As ROBINSON has pointed out, the nām ḍāk punctuates the pūja "in such a way as to articulate transitions from phase to phase" (1980: 114). In this sense, the name call is a framing device, demarcating smaller sets of ritual acts within the overall pujjā event. The name call is also significant as a communal performance because it is the only real ritual action in which audience members fully participate as performers. One must recall here that the level of noise generated is one indicator of a successful püja. Therefore, every voice is considered to be essential in arousing Dharmaraj. The call is repeated after every couplet to coerce him into the assembly. ${ }^{21}$ Through this verbal act, the deity not only "comes," but "becomes" to the response of the calls (ROBINSON 1980: 71).

When the bandana is completed there is a great deal of drumming and general noise-making to arouse Dharmaraj's interest, cajoling him to join the assembly for the duration of the püjā. Drumming continues for approximately twenty minutes, while the kol deyāâsi orders the bhaktyās to prostrate themselves in front of the temple. Once all of the devotees are on the ground, a lit incense burner is passed over their bodies several times by the kol deyāsis to the accompaniment of nām dạk. This is done to purify the devotees before they proceed through the village and rice paddies to the muktadhar pukur (pond of liberation). Elsewhere in Bengal this act is interpreted as a suicide threat (hatyā) to reinsure Dharmaraj's active participation (RoBINSON 1980: 154-155). The act is reminiscent of Ranjabati's (the textual hero Lausen's mother) impalement and Lausen's self-dismemberment in the Dharmamangal literary tradition to secure boons from the deity. In Goalpara, however, the kol deyāasi describes it simply as an act of obeisance. It is approximately 8 p.m. by now, and the crowd has grown considerably. Most audience members do not follow the procession to the pond; instead, they linger at the temple or return home for their dinner, while the devotees proceed to the pond.

The bhaktyās must complete their metamorphosis to a higher status before they can perform the feats of austerity (tapas) during the remainder of the pujja. To complete their change they must perform a procession through the village to the muktadhar pukur, transporting the large bāneśvar and an earthen pot called pürkals̄is (full pot) along with them. The objects are placed on the heads of two bhaktyās to the accompaniment of a new drumbeat played solely for this purpose. As the procession begins winding its way westward along the main path of the village, another rhythm, distinctively called cālān (moving), is played. During the procession incense burners, which are waved in the faces of the swaying bearers of the bạneśvar and pot, are be-

${ }^{21}$ On the notion of coercing the deity, see ROBINSON 1980: 110. See also MITRA 1972: 95, 170 and DAS 1983: 682. There is also textual evidence for another reason this practice is performed in Ghanaram's version of the Dharmamangal. See CAKRABARTTI 1962: 
ing carried by other devotees. The procession occasionally halts for a few minutes so that people in the houses along the main path may come out and receive the darśan (auspicious sight) of the parade. The rhythm played during these halts is called $n \bar{a}-$ canā bājnā (dance beat). The halts are said to bring luck and well-being to the individual who does the seeing. At these arresting moments the ritual objects are given to other bearers, so that each bhaktyā has the opportunity to carry one of the items before reaching the pond. After each halt, the drummers revert to the cālān beat and continue to move along the road, eventually proceeding into the open paddy fields. Drumming continues as the pace of movement quickens. Finally, the group arrives at the pond, where the drumming abruptly ceases when the devotees form a circle around Shibu $d \bar{a}$ on the eastern banks of the pond.

Once everyone is silent and seated, candles are lit and the ghăt bandanā (bathing step invocation) is recited. The text is once again read line by line from the folk-book by the officiating priest. Each section is repeated three times by the kol deyāisi, after which nām dâk is performed by all present. Then the bāneśvar is bathed in the pond by the mül deyasasi to the accompaniment of a nameless rhythm played only during bathing rituals. At the same time, the pot is filled with pond water - now considered the holy bath water of the bāneśvar - and some flowers. RoBINSON (1980: 89) interprets the pürkalsís and bāneśvar as female and male sexual symbols respectively, their conjunction resulting in a union to confer fecundity on barren women. The addition of the flowers to the pot is, in her estimation, an act of impregnation (ibid.: 90). Her perspective is adumbrated in the second and third verse of the ghat bandana with the mention of an unidentified water maiden and the sanctification of the water, which subsequently becomes the "waters of life" (ibid.: 91). The interpretation is viable insofar as fertility is seen as one of the goals of the püja. However, as conceived in Goalpara, fertility is only one form of mangal (auspiciousness) conferred during the pūjā.

The püjā cannot, therefore, be reduced to one common goal because the reasons given by devotees for performing seb $\bar{a}$ (service) imply that there is another more general and overriding communal concern for blessings (āsirtbād) and happiness (ānanda). My data is also corroborated by SARKAR's (1985: 253-263) information from another cluster of villages in Birbhum, where the frequency of fertility mentioned as a motivation for performing sebā is quite low. Nevertheless, curing barrenness must certainly be seen as one aspect of the püjäs efficacy.

More drummers have arrived from Shiyan by now, including Ratan Das, the new leader of the $\underline{d} h \bar{a} k \bar{k}$. They join the others as the devotees gather around Shibu $d \bar{a}$, the bathed bāneśvar, and the pürkalsīi. The uttarìyas are also placed around the spikes of the bạneśvar, while a banana and green mango are impaled on the plank's metal spikes.

A betal leaf coated with sindur (vermilion paste) and white sweetmeats to be distributed as prasād (food offerings) are also placed on the plank. Shibu $d \bar{a}$ then smears sindur taken from the bāneśvar on the foreheads of all the bhaktyās. At this point, he begins to recite from memory verses in hybrid Sanskrit from the Dharmapuja Bidhan, a liturgical manual consulted for correct procedure (BANDO- 
PĀDHYĀY 1323B.S.: 29). ${ }^{22}$ After reciting a brief passage in homage to Dharmaraj, he distributes the uttari yas to the low-caste bhaktyās. Interpretations differ, but most people are of the opinion that the bhaktyās enter into the deity's gotra (lineage) at this point, taking on the temporary status of Brahmans. RoBINSON's data from Baruipur, West Bengal reconfirms this point of view, since her field consultants are of the opinion that the devotees and the banneśvar become "affiliated in the mingling of the waters" (1980: 85), thereby causing the change in lineage. The water of the pürkalsi therefore represents this mingled water which passes from the ritual items to the ritual actors in due process. As a result, all become Dharmaraj's agents. ${ }^{23}$ After this, the guru mantra, the 101 names of gods, is recited as the full pot is passed around to each devotee as an act of communal solidarity. The recitation is accompanied by puspañnjali (flower throwing) for the băneśvar, and the consecrated flowers are then placed in the pot. After the consecration, the water in the pot is considered to be pabitra (holy). Thereafter it is referred to as śanti jal (peace water). It is said to undergo a transubstantiation during the preceding ritual because it becomes a metonymic replacement (cf. TAMBIAH 1968) for Ganges water. The sánti jal is then used in all of the pujjā rituals for general anointing.

The rituals of the first day seem to suggest that the bhaktyās acquire an elevated status far superior to their everyday caste positions in the local hierarchy. Although I cannot go into specific detail here (but cf. KOROM 1999) to describe all of the ritual activities performed after the above initiatory events, there is one ritual performance in particular that is pertinent to my concluding discussion of ritual status and caste politics. The performance, known as mukta snān (bath of liberation), occurs on the evening of the second day. The mukta snān ritual begins at approximately 10 p.m., after hours of secular performances by brass bands in the vicinity of the temple precincts. How the ritual begins is relevant to my earlier statements concerning the hypothetical equality of all bhaktyās during the püjā and Victor TURNER's related notions of liminality and communitas.

When the time comes to bring the deity out of the temple, the kol deyasisi organizes all of the low-caste bhaktyās in a straight line leading from the door of the temple to the end of the courtyard. Then he orders the bhaktyās to kneel down with their heads touching the ground, so that a human bridge is created. When this is done, Shanti Bhattacarjya, one of the Brahman bhaktyās, walks barefoot over the backs of

22 The text is in Bengali script, and is, according to my research associate, Abhijit Ghosh, "very bad Sanskrit." Shibu dā himself does not know the meaning of what he is reciting, but says that he learned it from a copy of the text housed in the university library at Shantiniketan. He insists that the appropriate passages must be recited, but need not be understood. His option of giving priority to the utterance over the meaning of the text lends credence to STAAL's (1979) argument concerning the "meaninglessness of ritual." The Dharmamangal of Ghanaram also mentions the liturgical use of this text. See CAKRABARTTI 1962: 90 .

${ }^{23}$ A minority of others believe that the transformation of status occurs during the reciting of the Dharma bandanā. It is interesting to point out here that the Brahman bhaktyās insist the lower caste devotees do not become Brahmans through this process, but only like Brahmans. Their opinion recapitulates hierarchy, rather than abolishing it or relieving it. Another more visible method of demonstrating Brahmanical dominance occurs the following night, and will be discussed in greater detail below. 
the other devotees into the temple to the sound of drumming. There are two indigenous interpretations of this act. When asked later, Shanti said that it must be done to show that Brahmans are superior to other castes. But the other devotees all claimed that this must be done because the Brahman's feet cannot touch the ground when he is entering the temple to bring bāba (father) out. Thus, from the Brahmanical point of view, the ceremony reinforces caste hierarchy, whereas low-caste people see it as a sacred act, and still claim that equality reigns during the püjā. While TURNER's point of view concerning the "betwixt and between" status of the people going through a rite of passage is well-taken, it is clear from this act that communitas is present in only a qualified sense, as suggested in the last section. Rites such as these do not eliminate caste restrictions, but simply alleviate some of the tension generated by social rules, allowing low-caste members of the community a more open forum for negotiations concerning rank and village affairs that may (or may not) be implemented when the village returns to mundane time. Because Brahmans never view the devotees as equal to themselves during the püjā, we must understand the notion of communitas as a potential ideal that is never fully actualized and subject to multiple interpretations dependent upon the various social positions of the actors involved. However, this observation raises the question of what, if any, usefulness the concept has in the study of caste-based society in India. In the final section, I should like to review the theories of TURNER and Arnold VAN GENNEP, his original source of inspiration, to draw some conclusions on the data presented in this essay.

\section{ASPECTS OF LIMINALITY}

In this concluding section I wish to explore two prominent theories used in the anthropological study of rituals that have been found to be useful for understanding the ways in which an individual undergoes status change during special periods of time. The first is that hypothesized by the folklorist Arnold VAN GENNEP in his 1909 book Rites of Passage, and the second, being liminality, a more recent theory constructed by the anthropologist Victor TURNER. ${ }^{24}$ TURNER was obviously influenced by VAN GENNEP's book, but built upon it by adding new ideas to the rites de passage paradigm. Both VAN GENNEP and TURNER attempt to make their theories universally applicable. As many critics have pointed out (e.g., BYNUM 1984; SALLNOW 1981), their conclusions may be somewhat broad and difficult to substantiate as universals, but their ideas do coincide with my data concerning the devotees of Dharmaraj in Goalpara to a certain extent. I do not intend to draw universal conclusions here, but rather attempt to show how the particular series of rites described above fits into the paradigm.

\footnotetext{
${ }^{24}$ I am aware of LINCOLN's (1991) critique of VAN GENNEP's spatial model of ritualized social passage based on his analysis of women's initiation rites in which he suggests enclosure-metamorphosisemergence as an alternative to separation-liminality-reincorporation. LINCOLN's alternative may apply to his own gender-specific data, but for the purposes of my discussion here, I focus solely on VAN GENNEP's work as a precursor to Turner's concerns discussed immediately thereafter.
} 
VAN GENNEP starts off with the basic premise that life consists of a series of passages or transitions. Life, according to him, is a "succession of stages with similar ends and beginnings" (1960: 3). Each of these transitions is marked by "ceremonies whose essential purpose is to enable the individual to pass from one defined position to another" (ibid.). He then goes on to subdivide each of these passages into three distinct phases. The first phase involves rites of separation (preliminal rites) in which the individual or group is ceremonially set apart from the rest of society. Phase two consists of rites of transition (liminal rites). This is the middle phase of the process during which the participant, having been removed from his or her everyday surroundings, becomes part of a smaller group for the duration of the transition. It is a new and awesome experience for the initiate in this paradoxical position. First of all, he has been removed from the larger body of society and becomes a part of a smaller one, itself set off from society. It is during this phase that many of the changes affecting the liminars occur. Finally, after the completion of the rituals, the third phase, known as rites of reincorporation (post-liminal rites), are put into play. The rite of reincorporation is the period when the liminal group is taken back into society to be part of the integrated whole once again (VAN GENNEP 1960: 11). This, then, is the threefold model proposed by VAN GENNEP at the turn of the century. I should point out here that rites of passage are usually construed as permanent changes, such as Hindu life cycle rites (samskāras). However, the transformation undertaken by devotees during the Dharmaraj pujja is a temporary and recurrent one, lasting only as long as the annual pujja itself, which in the Hindu idiom would be classified as a nitya (recurrent) ritual. It is important to keep this distinction in mind when attempting to understand the passage of the bhaktyās from this point of view, for a basic distinction is made between permanent changes and temporary ones in the Hindu context. However, a "rite of passage," as explicated by VAN GENNEP, can refer to any spatial or temporal process, whether permanent or recurrent, during which a change of status, behavior or character takes place.

TURNER took up where VAN GENNEP left off, but focused most of his writing on the liminal phase of the temporal or spatial passage. He further added the notion of symbolic death at the beginning of the rites, followed by rebirth during the final phase when the initiate is reincorporated into the larger body of society (TURNER 1974: 273). Liminality is a transient phase. It is a state in which the liminar is, as TURNER says, "betwixt and between all fixed points of classification" (1974: 232). It is an ambiguous state in the sense that its attributes are not like those of the past or the future. In liminality, the ritual initiate is passing through a symbolic domain in which many of the rules and regulations of his previous existence no longer apply, for he is in a strangely familiar, yet new world. This new world is a kind of "eternal now." The initiate is in transit between two cognitive realms. In the case of the Dharmaraj püjā, the bhaktyās are intermediaries between the community and the deity, so their centrality as ritual conduits of the deity's power places them in this paradoxical position of marginal centrality.

I have mentioned earlier that the Dharmaraj pujjā occurs during the month of Chaitra, a time when other auspicious rituals such as marriage are not performed in 
Goalpara. Although this is generally true in other Bengali communities where Dharmaraj pujja is not scheduled during the month of Chaitra, it is said that the curtailment of many other rituals during this special time makes the efficacy of the pujjā for Dharmaraj all the more potent. Certainly there is some concept of time during liminality, for, as we noticed, the punctual timing of ritual events is one of the major duties of the kol deyāisî. But there is a distinct sense of the abatement of profane time in which "the structural view of time is not applicable" (TURNER 1974: 238) because the normal duties of life are postponed for the bhaktyās during the days of the pujja event. The ritual specialists participate in a sort of eternal present, a mythical time during which an archetypal action of the god or ancestor is being repeated in the course of performing rites and significant actions (ELIADE 1958: 390ff). In the case of the Dharmaraj pujjā, such significant actions are based on the village's master narrative mentioned earlier and, as I have suggested elsewhere (KOROM 2000), implicitly replicate some of the events that occur in the Dharmamangal literature. This paradoxical time which is no time becomes a threshold which makes a direct experience with the sacred more accessible. The experience may be in the form of possession, an externally visible phenomenon which is rare in the Goalpara context, or an inward, intuitive one of which only the person undergoing the experience is acutely aware.

In liminality a clearer sense of understanding mankind's relationship to the cosmos is possible, for the initiate learns of his own culture through the narratives, symbols, and rituals involved in the püjä. The meaning of life is experienced directly by the bhaktyās through the symbols visualized and the actions performed during the event. Sometimes this knowledge is transmitted to younger bhaktyās by their senior counterparts through discourses orated during the early morning baths of purification each day during the püjā. New knowledge, unlike that learned during the preliminal phase, is gained through narrative acts. It is a deeper knowledge, a direct experiential awareness embodied by the individual, a point often made by new bhaktyās performing the austerities for the first time. For veteran devotees, the process is one of progressive insight as well as a renewed altered state. Newly acquired knowledge leads to the acquisition of power. It is a spiritual power available only to those who partake in the austere practices that must be performed during the püjā.

The new power is then applied by the bhaktya after his reincorporation into his society at the end of the rites. However, in the case of Goalpara, the acquisition and use of power gained during the rituals is very subtle. In one sense, the older ideals of the society are preserved by the symbols, for they are a storehouse of that which can be conceptualized and known. Through the rituals performed and the stories heard in liminality, one becomes more aware of one's own traditions. In his ritualized alienation, the bhaktyā is able to see things more clearly, for he becomes increasingly sensitive to the cultural issues he may take for granted during his day-to-day life. In this way, the traditional values of Hindu society in its localized context are preserved and passed on. As A. K. RAMANUJAN has stated: "Alienation from the immediate environment can mean continuity with an older ideal" (1973: 38). There is another 
slight paradox in this statement in the sense that the liminal phase offers a radical new knowing, but adheres to an older traditional ideal. Thus it seems that the pujja is, in part, a maintaining force in Goalpara society in that it preserves through replication the prescriptions given by the deity in the village's master narrative. At the same time, however, it can also reinforce social rules and the strictures of caste hierarchy.

Even those rules which are carried over into the liminal phase from the earlier one are relaxed by not being overemphasized during ritual practices performed while being a liminar. The best example of this is caste interaction during the pujjā. As we have seen, caste restrictions are not completely abolished during the bathing and shaving rituals, but notions of purity and pollution are certainly attenuated in many ways. The structural divisions of caste cannot be eliminated totally, but they can be confronted in various creative ways during the period of license provided to the devotees during their liminal period. The ideals of the pujjā support an antihierarchical stance on the ideological level, at least from the low-caste perspective. Yet they do not do away with them completely, for the problem of social stratification cannot be eliminated altogether through ritual practice. After all, the liminal phase will eventually end, and afterward everyone will once again have to work from within their own respective caste identities to negotiate the existential reality of status on an ongoing and daily basis. Thus, caste distinctions are not abolished, but rather negotiated by stressing cooperation, even though the Brahmanical interpretation reifies hierarchy within the context of the mukta snān performance. During the liminal phase of the rituals, a stronger sense of community consciousness emerges. It is what TURNER calls communitas. Communitas stresses reciprocity and comradeship during this phase. And through this mutual help, a stronger sense of ritual equality based on a recognition of identity differentiation emerges. The Goalpara scenario suggests that counter-status is subtly shaded and highly nuanced even during ritual functions, for it is understood in varying degrees by participants. In other words, perception of status change depends on the original status of the interpreter or actor.

The visual emblems displayed by the bhaktyās during the rituals are also relatively the same, regardless of rank or status. With the exception of the paitya, the sacred thread worn by Brahman bhaktyās, every devotee wears the same clothes and abstains from the same foods, thereby forging common experiences. As the bhaktyās perform the shaving rites and pass into the liminal phase on the first evening of the $p \bar{u} j \bar{j}$, they theoretically surrender all their possessions. Differences in property and wealth mark the status of the individual, which in turn makes communitas a difficult principle to which one must adhere. But during the rituals, all material possessions are left behind in the home. This symbolic act implies the bhaktyās' willingness to become part of a cooperative whole. By removing possessions, enhanced opportunity for communitas is nurtured.

During the rituals performed as part of the püjā egalitarianism is also present to a certain degree. The performance of rites for Dharmaraj's various manifestations amounts to potential symbolic reduction because there is a tendency of movement 
from diversity to unity. This movement is quite considerable if one takes into account the fact that low castes and Dalits (untouchables) are also included within the scope of this reduction. Quoting BABB again: "Worldly hierarchy is therefore momentarily eclipsed - reduced to relative insignificance by the overwhelming inclusiveness of the hierarchical opposition between the mundane and the divine" (1975: 60). In this way, the group of bhaktyās can achieve a sense of unity. But because the sacred/profane realms of life contain blurred boundaries in Goalpara, the dichotomy is not always as clear-cut as BABB suggests. Quite often the potential for unity is not actualized due to divisive factors that emerge during the event. For example, drunken brawls on the last day of the püjā have been known to occur among devotees, leading to factionalism within the ritual group.

The annual initiation of the bhaktyās is clearly a rite of passage. Their bathing and shaving rituals on the day before the pujjā begins mark their separation from the society of which they are a part, even though they are never isolated physically from their community in the sense of a pilgrim. The movement leads them into a liminal phase on the first evening of the pujjā when they receive their uttariyzas. This is the second stage of their passage, and they remain in this position until the conclusion of the rites three days later, when they unceremoniously toss their threads in the muktadhar pukur to signal both the end of the annual pujja and their return to normalcy. Upon throwing their uttari $\dot{y}$ as into the pond on the day after the pujja is over, they become reincorporated into the larger whole.

There is also another level on which this passage can be interpreted. Rather than to see it as one passage, the püjā can be seen as a successive series of transitional movements, ultimately ending up with a final reincorporation. Each day in and of itself is a rite of passage, for daily bathing and new austerities are performed in a highly ritualized manner to punctuate the experiences of devotees within even smaller frames of reference. What I am arguing is that we notice shorter rites of passage within the larger all-engulfing one. If, as I have suggested above, each bath is a symbolic death and rebirth, and each rite of separation also a rite of death ending with rebirth during the third phase, then the pujjā must be seen as smaller successive passages within the larger whole. I realize that this line of reasoning could be argued ad infinitum (e.g., each moment being a symbolic death and rebirth), but it is not my aim to carry the analogy beyond this point. I do feel, however, that understanding rites of passage in specific ethnographic contexts offers a potential to employ more fully the ideas of VAN GENNEP and TURNER, for the rites of Dharmaraj do suggest a sort of infinite regress into continuously smaller units of time, invoking a sense of time within time more reminiscent of TURNER's phrase "betwixt and between" than his notion of "time out of time." Time consciousness, then, in relation to ritual sequences could be seen from this point of view, which allows for the punctuation of smaller units of time within a larger temporal framework because bhaktyās share a sense of durée, as Henri Bergson once called it, an "inner time" which does not correspond to clock time.

This form of durée belongs to an experience of time which is shared by the devotees as a result of constant interaction generated by activities performed during 
the ritual sequence..$^{25}$ Moreover, time as a distinctively shared experience among the devotees lends more credence to the idea that these temporary renunciants are liminars. It is while playing the role of liminar that the bhaktyā is most empowered to speak on equal terms to his Brahman counterparts, potentially creating the circumstances to negotiate more egalitarian action among and within the village's local caste system.

\section{LITERATURE}

ABRAHAMS, Roger D.

1982: The Language of Festivals: Celebrating the Economy. In: Victor TURNER (ed.), Celebration: Studies in Festivity and Ritual. 201-219. Washington, D.C.: Smithsonian Institution Press.

APTE, Vaman Shivram

1985: The Practical Sanskrit-English Dictionary. Delhi: Motilal Banarsidass.

BABB, Lawrence A.

1975: The Divine Hierarchy: Popular Hinduism in Central India. New York: Columbia University Press.

BAILEY, H. W.

1961: Cognates of Pūjā. Adyar Library Bulletin 25/1: 1-12.

BANDOPHĀDHYĀỲ, Haricaraṇ

1988: Ba nigììa sabdakos. Kalikātā: Sahitya Akādemi.

BANDOPHĀDHYĀÝ, Nanīgopāl, ed.

1323B.S. Dharmmapūjā Bidhān. Kalikātā: Bañgīya Sāhitya-parișat.

BHATTACHARYYA, Asutosh

1952: The Dharma-cult. Bulletin of the Department of Anthropology. Calcutta University 1/1: 117-151.

1953: Dharma Worship in West Bengal. In: A. MITRA (ed.), The Tribes and Castes of West Bengal. 351-360. Calcutta: Government of West Bengal.

1975: Bāniglā Manigal Kābyer Itihās. Kalikātā: Mukharji eṇu kon.

BOURDIEU, Pierre

1977: Outline of a Theory of Practice. Cambridge: Cambridge University Press.

1989: Social Space and Symbolic Power. Sociological Theory 7/1: 14-17.

BYNUM, Caroline Walker

1984: Women's Stories, Women's Symbols: A Critique of Victor Turner's Theory of Liminality. In: Robert L. MoORE and Frank E. REYNOLDS (eds.), Anthropology and the Study of Religion, 105-125. Chicago: Center for the Scientific Study of Religion.

CAKRABARTTĪ, Ghanarām

1962: Śrī dharmmamañgal. ed. by Pìyuṣ Kānti Mahāpātra. Kalikātā: Kalikātā Biśvabidyālaỳ.

DAS, Rahul Peter

1983: Some Remarks on the Bengali Deity Dharma: Its Cult and Study. Anthropos 78: 661-700.

DE, Suśilkumār

1392B.S.: Bānglā Prabād. Kalikātā: E. Mukhārjī āyṇ̣ kong.

ECK, Diana

1981: India's Tirthas: 'Crossings' in Sacred Geography. History of Religions 20/4: 323-344.

1986: Gañaā: The Goddess in Hindu Mythology. In: John S. HAWLEY and Donna WULFF (eds.), The Divine Consort: Ràdhā and the Goddesses of India. 166-183. Boston: Beacon Press.

ELIADE, Mircea

1958: Patterns in Comparative Religion. New York: Sheed and Ward, Inc.

FALASSI, Alessandro

1987: Festival: Definition and Morphology. In: Alessandro FALASSI (ed.), Time Out of Time: Essays on the Festival. 1-10. Albuquerque: University of New Mexico Press.

${ }^{25}$ This is, of course, the crux of Alfred Schutz's mutual tuning-in relationship, which he defines as a "living together simultaneously in specific dimensions of time." See SCHUTZ 1951. 
GOLD, Ann G.

1988: Fruitful Journeys: The Ways of Rajasthani Pilgrims. Berkeley: University of California Press. GOLDSTEIN, Kenneth S.

1991: Notes toward a European-American Folk Aesthetic: Lessons Learned from Singers and Storytellers. Journal of American Folklore 104/412: 164-178.

HAZRA, R.C.

1985: Purana Literature as known to Ballālsena. Purana 27/1: 41-59.

KOROM, Frank J.

1990: Review of The Poison in the Gift. Journal of the American Oriental Society 110/3: 548-549.

1996: Oral Canon Formation in a Bengali Religious Community. Suomen Antropologi 21/2: 1222.

1997a: 'Editing' Dharmaraj: Academic Genealogies of a Bengali Folk Deity." Western Folklore 56/1: 51-77.

1997b: Oral Exegesis: Local Interpretations of a Bengali Folk Deity. Western Folklore 56/2 (1997): 153173.

1997c: Language, Belief, and Experience in Bengali Folk Religion. In: Eli FrANCO and Karin PREISENDANZ (eds.), Beyond Orientalism: The Work of Wilhelm Halbfass and its Impact on Indian and Cross-Cultural Studies. 567-586. Amsterdam: Poznan Rodopi B.V.

1999: 'To Be Happy': Ritual, Play, and Leisure in the Bengali Dharmaraj Püjā." International Journal of Hindu Studies 3/1 (1999): 1-58.

2000: Close Encounters of the Numinous Kind: Personal Experience Narratives and Memorates in Goalpara, West Bengal. South Asia Review 20/1: 19-45.

\section{KUMAR, Nita}

1988: The Artisans of Banaras: Popular Culture and Identity, 1880-1986. Princeton: Princeton University Press.

LINCOLN, Bruce

1991: Emerging from the Chrysalis: Rituals of Women's Initiations. New York: Oxford University Press.

MAJUMDAR, R.C., ed.

1943: The History of Bengal 1. Dacca: The University of Dacca.

MALINOWSKI, Bronislaw

1954: Magic, Science and Religion And Other Essays. New York: Doubleday Anchor Books.

MARRIOTT, McKim

1976: Hindu Transactions: Diversity Without Dualism. In: Bruce KAPFERER (ed.), Transaction and Meaning: Directions in the Anthropology of Exchange and Symbolic Behavior. 109-142. Philadelphia: Institute for the Study of Human Issues.

Mitra, Amalendu

1972: Rārher Sañgskriti o Dharmaṭākur. Kalikātā: Pharmā Ke. El. Mukhopādhyāẏ.

MUKHOPĀDHȲ̄Ỳ, Aśok

1990: Sañgsad Samārthaśabdakoṣ. Kalikātā: Sāhitya Sañgsad.

NEOGI, Maheswar

1951: The Worship of Dharma in Assam. Journal of the Asiatic Society of Bengal, Letters 17: $219-224$.

ÖsTÖR, Ákos

1982: Puja in Society. Lucknow, India: Ethnographic and Folk Culture Society.

RADHAKRISHNAN, R.

1965: On Pūjā. Indian Linguistics 26:225-228.

RAHEJA, Gloria Goodwin

1988: The Poison in the Gift: Ritual, Prestation, and the Dominant Caste in a North Indian Village. Chicago: University of Chicago Press.

RAMANUJAN, A.K

1973: Speaking of Śiva. London: Penguin Books, Ltd.

RĀY, Kāminīkumār

1971: Laukik Śabdakoṣ. Kalikātā: Lokbhāratī.

RISLEY, H. H.

1981[1891]: The Tribes and Castes of Bengal (2 volumes). Calcutta: Firma Mukhopadhyay.

RoBINSON, Sandra P.

1980: The Dharmapuja: A Study of Rites and Symbols Associated with the Bengali Deity Dharmaraj . Ph. D. Dissertation. Department of South Asian Languages and Civilizations. University of Chicago. 
ROHNER, Ronald P. and CHAKI-SIRKAR, Manjusri

1988: Women and Children in a Bengali Village. Hanover, Connecticut: University Press of New England.

SALLNOW, Michael J.

1981: Communitas Reconsidered: The Sociology of Andean Pilgrimage.” Man (NS) 16: 163-182.

SARKAR, R. M

1985: Regional Cults and Rural Traditions: An Interacting Pattern of Divinity and Humanity in Rural Bengal. New Delhi: Inter-India Publications.

SCHUTZ, Alfred

1951: Making Music Together. Social Research 18/1: 76-97.

SEN, Sukumar

1971: An Etymological Dictionary of Bengali: c. 1000-1800 A. D. (2 volumes) Calcutta: Eastern Publishers.

1975[1963]: Bāniglā Sāhityer Itihās 1. Barddhamān: Sāhitya Sabhā.

SINGH, Darshan

1981: A Study of Bhakta Ravidāsa. Patiala, India: Punjabi University.

SMITH, Jonathan Z.

1978: Map is Not Territory: Studies in the History of Religions. Leiden: E. J. Brill.

STAAL, J. F.

1963: Sanskrit and Sanskritization. Journal of Asian Studies 22/3: 261-275.

1979: The Meaninglessness of Ritual. Numen 26: 2-19.

STRENG, Frederick

1969: Understanding Religious Life. Encino, California: Dickenson Publishing Company, Inc.

TAMBIAH, Stanley J.

1968: The Magical Power of Words. Man (NS) 3/2: 375-208.

THIEME, Paul

1957: Pūjā. The Journal of Oriental Research 27/1: 1-16.

TURNER, Victor

1973: The Center Out There: Pilgrim's Goal. History of Religions 12/3: 191-230.

1974: Dramas, Fields, and Metaphors. Ithaca, New York: Cornell University Press.

1977: The Ritual Process: Structure and Anti-Structure. Ithaca, New York: Cornell University Press.

1979: Process, Performance, and Pilgrimage: A Study in Comparative Symbology. Delhi: Concept Publishing Company.

VAN GENNEP, Arnold

1960 [1909]: Rites of Passage. Chicago: University of Chicago Press.

YASSIF, Eli

1987: What is a Folk-Book? International Folklore Review 5: 20-27.

ZIMMER, Heinrich

1974: Myths and Symbols in Indian Art and Civilization. Princeton: Princeton University Press. 